\title{
The Perception of Civic Education Teachers on the Challenges of Building Character in the Pandemic Era of Covid 19
}

\author{
Hasmika $^{1 *}$, Ratu Aulia ${ }^{2}$, Tri Utami ${ }^{3}$ \\ ${ }^{1}$ Civic Education Department, School of Postgraduate Universitas Pendidikan Indonesia, Bandung, Indonesia \\ ${ }^{2}$ Civic Education Department, School of Postgraduate Universitas Pendidikan Indonesia, Bandung, Indonesia \\ ${ }^{3}$ Pancasila and Civic Education, Graduate School Universitas Negeri Yogyakarta, Yogyakarta, Indonesia \\ *Corresponding author. Email: hasmika276@upi.edu
}

\begin{abstract}
Education is a long-term investment for the future, and it brings benefits to an individual and also can shape and influence the character and mindset of a person. It means that education must not quit halfway especially in the condition of Indonesia facing the Covid-19 pandemic which had many negative impacts in all aspects of life, including in building character of students. The purpose of this study is to find out how civic education teachers perceive the challenges, obstacles and solutions to character building in the pandemic era. The results show that the challenges faced by civic education teachers in shaping the character of students in the pandemic era were the requirement of being able to optimize the learning in a very limited time, indifferent attitude of students in doing simple tasks, addiction to playing games while learning rather than participating in group discussions, and another obstacle found was the students were lazy to do online learning. House-to-house learning with a combination of civic education subject which is based on the values of Pancasila in character building becomes one of the solutions for building the character in the pandemic era of covid 19.
\end{abstract}

Keywords: Civic Education Teachers' Perception, Character, Covid-19 Pandemic

\section{INTRODUCTION}

In term, character is defined as human nature in general, where humans have many characteristics that depend on their own life. Character is a mental, moral, or ethical character that characterizes a person or group of people. The definition of "The stamp of individually or group impressed by nature, education or habit." Character are the values of human behavior related to God Almighty, self, fellow human beings, environment, and nationality which are manifested in thoughts, attitudes, feelings, words, actions based on religious norms, law, etiquette, culture, and customs. Character can also be interpreted as the same as morals and manners, so that the character of the nation is identical with national morals or national character. A nation with character is a nation with good character and character, on the other hand, a nation without character is a nation that does not or lacks good character or norms of good behavior [1]. It can be interpreted that character has an important role in life that will affect the progress of a nation, in this case every citizen, individual or community group, especially students as the nation's next generation, are expected to have good character to realize the progress of a country.In another formula it can be defined that character education is a system of instilling behavioral or character values to learning citizens which includes knowledge, awareness or willingness, and actions to carry out values, both towards God Almighty, themselves, others, the environment, and nationality so that we become our human beings.

This definition mandates that with all the differences in the Indonesian nation, education in Indonesia aims to make learning citizens have four main characteristics: religious people, people as individuals, social people, and humans as citizens of the nation. Based on these four main characteristics in educational practice in Indonesia, educational institutions are expected to develop habituation of thinking and acting with a focus on the eighteen values of life. The cultivation of these values is expected to form the character of students. The eighteen characters are as follows: religious, honest, tolerance, discipline, hard work, creative, independent, democratic, curiosity, national spirit, love for the country, respect for achievement, friendship, love peace, love to read, care for the environment, social care, and responsibility. The character-forming values that must be developed in each educational institution are 
basically universal character shapers of our human beings. In the midst of the diversity of nations in the world, Indonesian people must have an Indonesian character. This is a marker for the Indonesian nation which has a different identity from other nations [2].

In Indonesia, the importance of character education from an early age is also regulated in the Law. In Indonesia, the importance of character education for the Education System from an early age is also regulated in the National Education System Law No. 20 of 2003 which reads; National education has the function of developing capabilities and shaping dignified national character and civilization in order to educate the nation's life, aiming to develop the potential of students to become human beings who believe and fear God Almighty, have noble character, are healthy, knowledgeable, capable, creative, independent , and become a democratic and responsible citizen. However, recently the country of Indonesia and even the whole world is being tested by the Covid-19 Pandemic. Reported in Aljazeera (7/7/2020), there have been more than 535,000 people who died due to the Covid -19 virus. The disease caused by the new corona virus causes more than 11.4 million infections in 188 countries, which also brings significant changes and impacts to all aspects of life. The emergence of the Covid-19 outbreak has indeed had a major impact on all sides of human life, including in the world of education. The world of education seems to make the house an educational institution that can replace formal educational institutions. Many countries have decided to close schools, colleges and universities, including Indonesia[3]. This was done because of government instructions, and also on the grounds of preventing the spread of the Covid-19 virus. (Minister of Education and Culture Circular No.4 of 2020 concerning Implementation of Education Policies in the Emergency of the Spread of Covid-19, 2020) [4].

Explain that the spread of Covid 19 / Corona Virus first appeared in the city of Wuhan in China. It spreads very quickly and is deadly. It is spread through direct physical contact by humans through the mouth, nose and eyes. Efforts to break the chain of spreading Covid-19 were carried out by the government and religious institutions by issuing several regulations for the public to obey [5]. Coronaviruses are a large family of viruses that cause illness ranging from mild to severe symptoms. There are at least two types of coronavirus that are known to cause diseases that can cause severe symptoms, such as Middle East Respiratory Syndrome (MERS) and Severe Acute Respiratory Syndrome (SARS) [6].

Coronavirus Diseases 2019 (Covid -19) is a new type of disease that has never been previously identified in humans. Common signs and symptoms of COVID-19 infection include symptoms of acute respiratory distress such as fever, cough and shortness of breath. The average incubation period is 5- 6 days with the longest incubation period of 14 days. On January 30, 2020, WHO has declared it a public health emergency that is troubling the world. On March 2, 2020, Indonesia reported 2 cases of Covid-19 confirmation. As of March 16, 2020, 10 people have tested positive for corona.

This virus spreads very quickly and has spread to almost all countries, including Indonesia, in just a few months. This has led several countries to implement policies to impose lockdowns in order to prevent the spread of the Corona virus. In Indonesia itself, a Large-Scale Social Restriction (PSBB) policy was implemented to suppress the spread of this virus. and there are many more policies that have been carried out until the new normal policy is new, however, Indonesia still cannot be separated from this problem. The death rate due to the cor ona virus in Indonesia is the highest in Asia after China, died 181 people, the death rate is $9.11 \%$, the number of corona virus cases is 1,986 cases, 134 people have recovered. recovered 164 people and died 198 people. Given that the Covid-19 outbreak is a global problem that has hit parts of the world including Indonesia, which also affects all aspects of life, including in the world of education which also has an impact on changing the character of students where students are the next generation of the nation and education is expected to be able to become a place to give birth to a person with noble character. . Such a great hope for the sake of giving birth to a person with noble character or good character encourages schools as a place for formal education to carry out various things for these purposes. This is what motivates the author to write about "The Perception Of Civic Education Teachers On The Challenges Of Building Character In The Pandemic Era Of Covid 19" [7].

\section{METHOD}

The approach in this research is to use a qualitative approach. Qualitative research is research that intends to understand the phenomena experienced by research subjects such as behavior, perception, motivation, action etc. holistically and by means of descriptions in the form of words and language, in a special natural context and with take advantage of various natural methods. The type of research approach is descriptive [8]. On the other hand, a qualitative approach which is a holistic approach that involves finding in a natural or "naturalistic" model, researchers develop a higher level of detail than actual experience [9]. In the study, the authors took several subjects of Pkn teachers who taught in several schools, especially in West Kalimantan province to get information about the challenges of obstacles and solutions to character building in the pandemic era which the author tries to get based on data sources, then the writer pre-presses based on events and supporting theories. To get answers to the problems in this study. Data collection techniques in this study used techniques, namely 1) observation and 2) 
interviews. interactive model qualitative data analysis according to Miles, Matthew B and A. Michael Huberman which consists of three activities occurring simultaneously, namely 1) data reduction, 2) data presentation, 3) drawing conclusions / verification [10].

\section{RESULT AND DISCUSSION}

\subsection{The Perception Of Civic Education Teachers On The Challenges Of Building Character In The Pandemic Era Of Covid 19}

The development of national character and identity are noble ideals that must be realized through the provision of directed and sustainable education. The inculcation of moral, moral, and ethical values as stated in the Law of the Republic of Indonesia Number 20 of 2003 concerning the National Education System must be the main basis for designing, implementing and evaluating the national education system. National education has the function of developing capabilities and shaping dignified national character and civilization in order to educate the nation's life, aiming to develop the potential of students to become human beings who believe and fear God Almighty, have noble character, are healthy, knowledgeable, capable, creative, independent, and become citizens of a democratic and responsible [11].

The aim of national education as a whole is the development of student character.Of course, in this case the character that is expected to always appear in students is good character, referring to the explanation above that character building is very important and must not die in the middle of the road, especially in the current conditions of Indonesia. experiencing problems that cannot be underestimated and even taken seriously, namely the Covid-19 pandemic, we must always strive without losing the cultural roots and basic values of Pancasila that we already have as a reference in acting and behaving in everyday life. Of course, in this case the expected character is always good character. character as a subjective assessment of a person's personality relating to personality attributes that can or cannot be accepted by society. Character is the overall nature and disposition that has been controlled in a stable manner which defines an individual in the whole psychic behavior system which makes it typical in ways of thinking and acting [12]. Another opinion states that character refers to a series of attitudes, behaviors (bahaviors), motivation (motivation), and skills (skills). The character comes from Greek which means "to mark" or mark and focus how to apply the value of goodness in the form of action or behavior [13]. The government's effort in shaping the character of students is basically a shared responsibility between the government, school institutions and family institutions. In the world of education the role of the teacher really has a role in shaping the character of students as identifying at least nineteen roles of teachers in learning. The nineteen roles of teachers in learning, namely, teachers as educators, instructors, mentors, trainers, advisors, innovators, models and role models, individuals, researchers, creativity boosters, viewers, routine workers, camp shippers, storytellers, actors, emancipators, evaluators, preservatives, and as culminators [14]. In line with the concept, the teacher is the person entrusted by God to carry out education and teaching according to the gifts that have been given to him. "The teacher is one of the human components in the teaching and learning process, which plays a role in efforts to form potential human resources in the field of development." In addition, teachers are a human element in education. "Teachers are human resource figures who occupy positions and play an important role in education" [15].

Moreover, Civics teachers are often associated as a forerunner to the formation of participant character, whether success or failure lies in the PKN teacher as Sumarsono explained that Pancasila and Citizenship Education Teachers are expected to focus on character building as citizens who can understand and be able to carry out their rights and obligations to make quality citizens. a country that is smart, skilled and has character mandated by the Pancasila and the 1945 Constitution [16].

Based on the author's interviews with several Civics teachers, namely Pkn teacher at Takhasus Alquar'an Ngabang Hedgehog High School, Pkn teacher at Makarim Elahlak Islamic Boarding School and Pkn teacher at SMPN 3 Satu Atap Sejangkung. which is used as a resource writer to get information about how Pkn teachers' perceptions or responses regarding the challenges, obstacles and solutions to character building during the Covid-19 pandemic reveal that the challenges in character building in the Covid-19 pandemic era are; (1) educators are required to be able to optimize learning with short meeting hours, (2) indifferent conditions of students in doing simple tasks; (3) addiction to playing games while learning rather than following group discussions; (4) Another obstacle found was the condition of students being lazy to do online learning. Seeing the four problems earlier, it is clear that this will make the character of students from the implementation of Pancasila values as a guide in behaving in everyday life.

While the obstacles to character building students in the Covid-19 pandemic are the lack of parental encouragement, participation of parents in supervision as long as their children take online learning, which in the learning process is certain that every educator provides motivation and pursuit of good attitudes to students but lack of supervision and motivation. students make them display an attitude of indifference or indifference, a loss of creativity and a tendency to not care about their achievements as explained that according to the Ministry of Education and Culture of the Republic of Indonesia there are various kinds of characters, namely religious, honest, tolerance, discipline, 
hard work, creative , independent, democratic, curiosity, national spirit, love of the country, respect for achievement, friendly, peace-loving, fond of reading, care for the environment, social care, and responsibility [17]. The above characters must always be raised by students so that they have good character to face the year 2045 or what is often called the golden generation. "This nation must be built by prioritizing character building. Because character building is what will make Indonesia a great, advanced and glorious and dignified nation. If character building is not carried out, then the Indonesian nation will become a nation of coolies ". From a philosophical perspective, it is said that education without character, this is sins the basis for misery in the world, The essence of education is to recognize truth. Let your secular education go hand in hand with spiritual education [18].

Solutions that can be proposed to minimize the above problems Home-to-house learning, namely the teacher comes home to provide face-to-face learning once a week to provide character strengthening to students and the coordination of teachers and parents in supporting and providing motivation and parental supervision can be used as a solution in supporting character building in the era of the Covid pandemic 19. As such, it is mandatory for teachers at schools and parents at home to educate students and their daughters to become intelligent and noble people [19]. For this reason, the role of teachers and parents in instilling this honest character is very important. In order to be effective and efficient, teachers must have four competencies in order to be able to provide good examples to students. Meanwhile, parents must also have adequate understanding and knowledge as well as a good personality so that they can provide an example to children, especially related to character building in accordance with Pancasila. There are many steps that can be carried out, and the most important is how to instill a complete awareness in children so that honesty is a positive thing for their lives, so that children are able to have an understanding of the differences in good and bad characters and what the consequences are in life [20].

The solution proposed by the two is believed to be a combination of Civics subjects which are based on the values of Pancasila in character building to be one of the solutions carried out for character building in the Covid 19 pandemic era. declining national character. Pancasila is a critical and rational reflection as the basis of the state and the cultural reality of the nation, with the aim of obtaining the main points of understanding in a fundamental and comprehensive manner. Pancasila as an ideology in terms of state ideology or national ideology is still maintained. However, along with the misinterpretation that Pancasila is used to strengthen state authoritarianism [21]. One of the characteristics of any authoritarian power is that it always considers ideology as all-important, which is closely related to social stability or cohesion. But the assumption that attempts to homogenize ideologies are important in order to create stability and strengthen community cohesion is misleading [22].

However, history has proven that the material value of Pancasila is a source of strength for the struggle of the Indonesian nation. Pancasila values are both binding and impetus in the effort to uphold and fight for independence so that they become evidence that Pancasila is in accordance with the personality and desires of the Indonesian people. Pancasila is a sublimation of cultural values that unites Indonesian people of various ethnicities, races, languages, religions, islands, into one nation. The values contained in Pancasila are the soul of personality, and the way of life of people in the archipelago since a long time ago [23]. Therefore character education aims to develop values that shape the character of the nation, namely Pancasila which includes: (1) Developing the potential of students to become good-hearted, good-minded and well-behaved people; (2) Building a nation with Pancasila characteristics; (3) Developing the potential of citizens to have a confident attitude, be proud of their nation and country and love humanity. We as citizens must be aware that character building is a shared responsibility of elements of education, society and family [24].

\subsection{Our Contribution}

This paper describes how Civics teachers perceive the challenges, obstacles and solutions to character building in the pandemic era. This paper also examines in detail the obstacles encountered in character building during the pandemic and the author provides one solution, namely house-to-house learning with a combination of Civics subjects which is based on the values of Pancasila in character building to be one of the solutions for character building. in the era of the Covid pandemic 19. Because as citizens, they must be aware that character building is a shared responsibility of elements of education, society and family. Of course, the formation of this character will not be separated from the values of Pancasila which are the references and guidelines for life in daily behavior.

\subsection{Paper Structure}

The rest of this paper is orginized as follows: Part 1 introduces the background for the writing of this paper, in which the author wants to see Pkn teachers' perceptions of the challenges of character building in the Covid-19 pandemic era. Section 2 presents the methods used in the process of compiling the results and discussions. Then in Section 4 the results and discussion discusses how the challenges, obstacles and solutions for character building in the pandemic era. Section 5 concludes the paper and provides direction for future research. 


\section{CONCLUSION}

Character building is a noble ideal that must be realized through the implementation of directed and sustainable education based on the Law of the Republic of Indonesia Number 20 of 2003 concerning the National Education System which is very important and should not die in the middle of the road, especially in the current conditions Indonesia is experiencing problems which cannot be underestimated and even taken seriously, namely the Covid-19 pandemic, we must always strive without losing the cultural roots and basic values of Pancasila that we already have as a reference in acting and behaving in everyday life. The results of the study show the challenges in character building in the Covid-19 pandemic era, namely; (1) educators are required to be able to optimize learning with short meeting hours, (2) indifferent conditions of students in doing simple tasks; (3) addiction to playing games while learning rather than following group discussions; (4) Another obstacle found was the condition of students being lazy to do online learning. Meanwhile, the obstacle to character building students in the Covid-19 pandemic is the lack of parental encouragement, parental participation in supervision as long as their children participate in online learning. Therefore, to minimize the influence of the pandemic's impact on the character of students Home-to-house learning, namely the teacher comes home to provide face-to-face learning once a week to provide character strengthening to students and coordination of teachers and parents in supporting and providing motivation and supervision of people in the process. Online learning and a combination of Civics subjects which are based on the values of Pancasila in character building are one of the solutions for character building in the Covid 19 pandemic era. Pancasila. This paper is expected to be a reminder that shaping the character of students is not easy, but it requires persistence and responsibility for educational institutions, society and family institutions. It must be realized that character building in the midst of globalization, especially Indonesia is facing a major problem, namely the presence of the Covid-19 pandemic has not made educational institutions, communities and family institutions forget the important task of always shaping the character of future generations so that Indonesia can compete with the state - other developed countries.

\section{ACKNOWLEDGMENT}

This article is supported by Rexi Dwi Karmadi, S.Pd., because she has provided suggestions so that the authoress can complete this article. Then, the authors also conveys to Thomy Sastra Admaja, SH.M.Pd as proofread of this article and the committee The International Conference on Character Education (ICCE) University of Muhammadiyah Semarang as a reviewer for this article.

\section{REFERENCES}

[1] Yusuf, M. (2013). Membentuk Karakter Melalui Pendidikan Berbasis Nilai. Al-Ulum, 13(1), 1-24.

[2] Najmina, N. (2018). Pendidika Multikultural Dalam Membentuk Karakter Bangsa Indonesia. JUPIIS: Jurnal Pendidikan Ilmu-Ilmu Sosial, 10(1), 52-56.

[3] Syah, R. H. (2020). Dampak Covid-19 pada Pendidikan di Indonesia:Sekolah, Keterampilan, dan Proses Pembelajaran. Salam: Jurnal Sosial Dan Budaya Syar-i, 7(5), 395-402. https://doi.org/10.15408/sjsbs.v7i5.15 314.

[4] Lubis, Masruroh, et al. Pembelajaran Pendidikan Agama Islam Berbasis E-Learning (Studi Inovasi Pendidik MTS. PAI Medan di Tengah Wabah Covid19).Fitrah, vol. 1, no. 1, 25 Jul. 2020, pp. 1-18.

[5] Syafrida, S., \& Hartati, R. (2020). Bersama Melawan Virus Covid 19 di Indonesia. SALAM: Jurnal Sosial dan Budaya Syar-i, 7(6), 495-508.

[6] Dewi, W. A. F. (2020). Dampak COVID19 Terhadap Implementasi Pembelajaran Daring di Sekolah Dasar. Edukatif: Jurnal Ilmu Pendidikan, 2(1), 55-61.

[7] Yurianto, Ahmad, Bambang Wibowo, K. P. (2020). Pedoman Pencegahan Dan Pengendalian Coronavirus Disease (Covid-19) (M. I. Listiana Azizah, Adistikah Aqmarina (Ed.).

[8] Moleong, Lexy J. (2012). Metodologi Penelitian Kualitatif. Bandung : PT Remaja. Rosdakarya.

[9] Gumilang G.S.(2016) Metode Penelitian Kualititatif dalam bidang bimbingan dan konseling.Jurnal Fokus Konseling Volume 2 No. 2, Agustus 2016 Hlm. 144-159.

[10] Miles,M.B, Huberman,A.M, dan Saldana,J. (2014). Qualitative Data Analysis, A Methods Sourcebook, Edition 3. USA: Sage Publications. Terjemahan Tjetjep Rohindi Rohidi, UI-.

[11] Given, M, Lisa.(2008) "The Sage Enclyclopedia of Qualitative Research Method", Singapore. Sage Publisher

[12] Zubaedi, (2011). Pendidikan Karakter : Konsep dan aplikasi dalam lembaga Pendidikan. Jakarta: Kencana 
[13] Zainal dan Sujak. (2011). Panduan dan Aplikasi Pendidikan Karakter. Jakarta : Gaung Persada Press.

[14] Mulyasa. (2007). Standar Kompetensi dan Sertifikasi Guru. Bandung: PT. Remaja Rosdakarya.

[15] Telaumbanua, A. (2018). Peranan guru pendidikan agama kristen dalam membentuk karakter siswa. FIDEI: Jurnal Teologi Sistematika dan Praktika, 1(2), 219-231

[16] Alfiati, L. N., \& Trisiana, A. (2017). Peran Guru Ppkn Dalam Membentuk Karakter Siswa Sebagai Pendukung Revolusi Mental (Studi Kasus Pada Siswa Smp Negeri 4 Karanganom Kabupaten Klaten). Jurnal Global Citizen: Jurnal Ilmiah Kajian Pendidikan Kewarganegaraan, 3(1).

[17] Manullang, B. (2013). Grand Desain Pendidikan Karakter Generasi Emas 2045. Jurnal Pendidikan Karakter, (1).

[18] Al-'Akk, Syekh Khalid bin Abdurrahman, (2006).Cara Islam Mendidik Anak.Yogyakarta: AdDawa.

[19] Rochmawati, N. (2018). Peran Guru dan Orang Tua Membentuk Karakter Jujur pada Anak. Al-Fikri: Jurnal Studi Dan Penelitian Pendidikan Islam, 1(2), 1-12.

[20] Wahyudi. 2009. Kepemimpinan Kepala Sekolah Dalam Organisasi Pembelajaran. Bandung: Alfabeta.

[21] Basrowi.(2012). Evaluasi Belajar Berbasis Kinerja. Bandung: Rineka Cipta.

[22] Anas, M., (2020). Etika Sosial Pancasila dan Kebijakan Wabah Corona. Di akses pada 2 Juni 2020 pukul 01.03 WIB di http://macapat.pmpk.ub.ac.id /etikasosial-pancasila-dan-kebijakan-wabah-ko rona/.

[23] Rachmah, H. (2013). Nilai-nilai dalam pendidikan karakter bangsa yang berdasarkan Pancasila dan UUD 1945. E-Journal WIDYA Non-Eksakta, 1(1).

[24] Kemdiknas. (2011). Panduan Pelaksanaan Pendidikan Karakter. Jakarta 